\title{
Cheating In Business Schools, The Millennial Generation, Gender And Racial Diversity: Has The Paradigm Shifted?
}

David L. Mathison, Loyola Marymount University, USA

\begin{abstract}
Cheating in college is not new. In 1960 over 50 percent of students admitted they cheated. In the second decade of the $21^{s t}$ century has anything changed? This research project looked at three possible new variables, the Millennial Generation, Gender, and Diversity. Results suggest the amount of reported cheating remains the same even with current "Gen Yers" in college. There was also no measured difference in cheating between men and women students. Finally, the present study found that Asian-Americans admitted to cheating far more than the average and Latino-Americans reported to have cheated in college far less than the average current students in college. This paper concludes with the following three implications: 1) Current college undergraduates, "the Millennial Generation," may actually be more ethical as measured in this study than their Boomer Parents. 2) Women and graduates as measured in this study may be more prone to college cheating than women students in the past-trends of a new post-feminist generation? 3) Finally, diversity and the core values embedded in America's individual subcultures, such as Asian and Hispanic, appear to significantly influence ethical choices of today's college students - diversity within the melting pot?
\end{abstract}

Keywords: cheating, ethics, business students, diversity, gender, race Millennial Generation, changing values.

\section{INTRODUCTION}

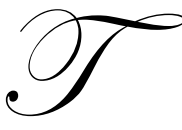

his plague is getting worse by the day-and now with technology and Wall Street's double meltdown - college cheating has reached absolutely endemic levels! Just ask any professor who's all too willing to share their opinion.

But is it true?

Is cheating truly growing worse everyday in everyway? Is in fact the millennial generation, children of the boomers, with their newfound technology, flexibility, confidence, toleration, and religion really taking every shortcut imaginable? Do the post-feminist women now in their early 20s genuinely seek advantages over their male counterparts no matter what the cost? Does the newfound strength of first generation Hispanics or intensely goaldriven Asians translate into compromising core values inherent in each of their historic cultures?

The purpose of the present paper is to explore exactly these questions concerning cheating in today's business schools. Is it growing worse? Is the millennial generation any different from generation Y or the boomers? Are men and women similar in values, and finally are the values among our new diverse population any different than those of traditional students?

A review of the literature will focus on current trends in college cheating, possible changes between the generations, possible changes among men and women, and possible changes in students of diverse backgrounds. 
Then outcomes of a new four year longitudinal study will be reported. The findings will be analyzed followed by concluding observations. The paper will end with future implications for university educators over the next 10 years.

\section{THE RECORD OF STUDENT CHEATING IN BUSINESS SCHOOLS MAY NOT BE PRETTY, BUT IT IS ALSO NOT CHANGING}

With alarming regularity, from 1960 to the present, the reported story all seems the same-college cheating is endemic and it is getting worse by the hour-but is it allowed? Here is a look at the actual studies. In 1960 Van Nostrand first struck the alarm in the Journal of Applied Social Research with an article titled, "Student Dishonesty and its Control in College." Here he reported that nearly two-fifths of the students polled admitted to cheating. Zastrow looked at cheating among graduate students and reported in 1970 in the Journal of Educational Research that at least $40 \%$ of students reported having cheated. In the landmark study by John Baird, 1980, he reported that fully $75 \%$ of those surveyed in college confessed to cheating and he argued that "reported incidences of cheating have now increased over the past few decades" (i.e., 1960s - 1980s). In 1986 Haines et al. argued that exactly 50\% of the students polled admitted to cheating, LaBeff et al. in 1990 reported 54\% cheating while Maramark et al. (1993) estimated the number closer to $60 \%$ to $75 \%$.

Diekhoff et al. (1996) in another "landmark study" titled, "College Cheating: 10 years later," suggests the rate of violations have grown from 54.1\% in 1984 to 61.28 in 1994 and of course, "it is getting worse." In more recent articles there are also reports of similar findings.

McCabe in 2005 found in his study involving some 80,000 students that the actual percentage of students who admitted to any form of cheating was closer to $60 \%$. Finally, the Kenan Institute for Ethics at Duke University surveyed nearly 50,000 students in 2006 and found that 54\% admitted to cheating in college (Beucke, 2006). Clearly, the trend-line on college cheating is flat as a pancake and it has been flat and unchanging for the past 60 years. Students are students are students - and given the opportunity to cheat, be it the "original great generation" on the GI Bill or the post 9/11 generation Xers, it is predictable that about half the students at a given college will admit to cheating.

One final observation on college cheating - consistently, the literature suggests that business students cheat far more than the average college student (Thompson et al., 2004; Carroll, 2006; Klein et al., 2007).

\section{THE MILLENNIAL GENERATION - THE POST-MODERN MORAL RELATIVISTS - A NEW KIND OF ETHICS?}

With 60 million and counting, these adult children of the boomers are the biggest thing to hit the American scene since 1972. One in three is not Caucasian, one in four live with a single parent, three in four have a working mother and they are digital natives while their parents are digital immigrants (Business Week, Feb 15, 1999). A second article observes that these "Gen Yers" will spend over 9 hours a day using media and technology and shun TV. They are racially and culturally tolerant, grew up with Goosebumps and Harry Potter fiction and some argue they are "failure to launch" Peter Pans - avoiding careers and living with their parents longer. They are more pragmatic and get along well with their parents but reject their parents' counter culture "change the world" perspective. Forty-eight percent believe in God, 50\% report they pray before eating and fully one-third report they attend church weekly (Wikipedia, 2010).

While cynical they have a distinctly practical world view and tend to be consensus builders. Robert Tauber (2006) notes the "Gen Yers" he studied actually held stricter views against cheating than their boomer university faculty instructors.

Speaking of this apparent and unexpected integrity, one new book positively characterized these civic minded twenty-something year olds in the book titled Millennials Rising: The Next Great Generation (Howe et al., 2006). 


\section{MEN AND WOMEN AND CHEATING REALLY THE FAIRER SEX?}

Titled, "Gender and Dishonestly," Ward et al. (1990) examined gender differences in college cheating and reported women to be less likely than men to cheat, but he added they did tend to make more excuses for their behavior. In Teaching and Psychology, Davis (1995) reported similar findings. In the major study completed by Smith et al. (2004) and published in the Journal of Business Ethics, males reported they engaged in more cheating behaviors than women and this same article suggested women may have a "stronger moral compass." Don McCabe (2005) again reported identical findings as did Beltramini et al. (2004) who observed that "female students in particular are more concerned about ethical issues than their male counterparts."

Premeaux (2005) on the other hand in an equally significant study reported in the Journal of Business Ethics to have found no significant difference in cheating behavior based on gender alone. Finally, in the Journal of Education for Business, Smyth et al. (2009) conclude their study involving mostly religious affiliated colleges stating that "female students are more ethical." There is a strong pattern reported in the literature that in general, women students do tend to be more ethical. However the 2005 Premeaux study suggests a possible fundamental shift in this current generation of women. Today's women's values may now be nearly identical to their male colleagues.

\section{GENERATION Y AND THE NEW RACIAL DIVERSITY: DOES CULTURE INFLUENCE CHEATING BEHAVIOR?}

According to the Handbook of Ethical Research with Cross-Cultural Populations and Community (Trimble et al., 2004), the Millennial generation now representing fully half the world population has also increased Latino and Asian growth in the U.S. by $12.6 \%$ and $4.0 \%$ respectively. In trying to predict possible trends toward college cheating, Shepherd, et al. (2002) reported no significant difference between Latinos versus Anglos, or Asians versus Anglos. S. R. Premeaux (2005) on the other hand, reports that Asian-Americans were significantly less likely to cheat versus Anglos suggesting that there is considerable shame culturally if one is caught. Three other research studies however report a different trend. Thompson et al. (1995) report higher than average rates for cheating among Asian-Americans and argues, "Learning not to cheat is the more difficult task given within this culture students are taught to memorize and copy well respected authors and leaders." These researchers continue by observing "their (Asian) educational system emphasizes the importance of grades more than the way in which one achieves those grades." In Research in Higher Education, Die Khoff et al. (1999) reported similar findings among Japanese students. And finally Carl Malinowski (2004) in his article titled, "Differences in Ethical Attitudes of Undergraduates of Asian and U.S. Ancestry," reported that Asian-American college students "have distinctive values, beliefs and customs which may cause this population to feel less guilty about what are generally considered questionable behaviors. This research adds that these students may "simply not believe that certain acts are wrong." Stipek (1998) reported similar findings.

Comparing Latino-Americans versus Anglo-American, Baker (2000) found in his research study that the Latino group consistently had higher levels of moral judgment scores and ethical scores than their Anglo counterparts. Mark Lanier (2006) found a similar pattern when he surveyed 1262 college students directly on the issue of academic cheating. He found $41.6 \%$ of Anglos admitted to cheating versus only $11 \%$ of their Latino colleagues.

Accordingly, based on this review of literature, three possible outcomes are predicted: 1) On millennial generation levels of college cheating, it is predicted a slight decrease in cheating, 2) On differences between male and female levels of college cheating, it is predicted that female students will cheat significantly less. Finally on cultural differences in cheating, it is predicted that Asian-American students will cheat above the norm and LatinoAmerican will cheat at levels below the norm of their fellow classmates. 


\section{METHOD}

\section{Subjects}

In this study 163 male and 189 female business college seniors enrolled in a medium-sized private university located in Los Angeles participated in a four-year longitudinal research project.

\section{Procedure}

Each student wrote a two-page essay which was assigned in a required senior course titled, "Business as an Institute of Society." Students were first shown a 40 minute edition of Primetime Live titled, "Cheating Crisis in American Schools," hosted by Charles Gibson which reported on High School and College Cheating. Several studies were discussed in the report along with researchers who noted that about $75 \%$ of American high school students and about 50\% of college students admitted they had cheated in school. Many of these students were interviewed with responses ranging from confessed guilt to pure pride of having gotten away with it.

The subjects in this present study were asked to then respond to the DVD by writing an essay answering the following question, "Why act ethically if you know you will not get caught?" They were urged to be both honest and candid and it was explained that this assignment would not be graded.

The researcher conducted a blind content analysis where names, gender, and race were not known. Unlike the commonly used self-report studies where subjects are asked to admit wrong doing, this study drew conclusions from the content shading and tone of the essay. This method is consistent with several new mythologies reported that have equal concerns with "word-deed," disconnect issues inherent with self report research (Karlins et al., 2000; and Thompson et al., 2004). Interestly, in about $85 \%$ of these essays, students forthrightly announced if they had cheated or not and often the kind of cheating and amount was also freely disclosed. The balance of these essays consistently fell into two groups. One group in the first essay paragraph expressed outrage concerning the lack of ethics of the students in the DVD. The other type of essay generally went on for two pages arguing either this is a "very very complex" issue or there are many "very good reasons" why a person would cheat.

\section{The Findings}

\section{Millennial Generation}

Consistently over the four years of this study, about half of the students admitted to cheating. The exact combined percentages were 47\% "Yes, I have cheated" and 53\% "No, I have not cheated." Also over the four years of this study the percentages did not vary more than four percent.

\section{Gender Differences}

It was found that the difference between the percentages of women who cheated versus the percentages of men who cheated was statistically negligible. Forty-eight percent of the women in this study admitted to cheating in college. Their male counterparts who also admitted to cheating in college were a near equal, 47 percent.

\section{Cultural Differences}

In the area of cultural differences, both Asian and Latino patterns were also measured. The cultural background was assessed both from content analysis including often an open discussion about their family and cultural roots plus from surnames. Certainly this was not an exacting measurement but this did result in sufficient numbers so that reliable patterns could be detected. Significant and convincing patterns were found of the Asian students in the study - fully 67 percent admitted to cheating in college - a considerable number above the average number in the present study of about $50 \%$ overall. Of the Latino students in the same study who also admitted to cheating in college, only $31 \%$ indicate they have cheated. This number is clearly significantly below the average overall number of $50 \%$. 


\section{DISCUSSION}

Clearly the present findings which are also consistent with a literature review spanning some 50 years suggests we need to put to rest once and for all the tired rag on every new generation - "Going to Hell in a Handbasket" (Palmer, 1987).

The millennial generation, children of the boomers are no different than any other twenty-something generation - be it the "Great Generation" following WWII, the Boomers, Generation X or the Gen Yers in our classrooms today. Cheating in college seems more a function of age, opportunity and stress rather than generations. From the studies reported in 1960 (Van Nostrand) to the present about 50\% of college students admit to cheating. Period!

Gender differences found in the present study actually seem to go cross-grain to the predictions in the literature which suggest women students consistently cheat less than men. The present study found virtually no difference between men and women (one percent). Explaining this change is more of a challenge. Have the women of the post-feminist movement become more pragmatic and, perhaps more ambitious at the possible costs of their own integrity? The most recent studies appear to be mixed in their observation of gender trends. Recall that Premeaux (2005) reported no significant differences between men and women in cheating behavior. Is it possible the millennial generation students are ushering in a gender neutral ethical pragmatism?

Perhaps the most significant finding in the present study is how Asian and Latino college students differ from their Anglo counterparts concerning attitudes and possible behavioral patterns of cheating in college. The literature suggests two conflicting cultural pulls for Asian-American college students. On one side is the possible shame and guilt inherent in the risk of being caught, therefore motivation not to risk. On the other side is a strong cultural imperative for success and tangible achievement often at considerable cost both in time and possible personal integrity.

While one may argue the Asian-American is an "academic native" familiar with the educational system and skilled in mastering this arena, the Latino-American is on the other hand, a first generation "academic immigrant." Likely the vast numbers of Latino college students are "firsts" in their family to enter university level education. They may lack the skills or the history of mastering or manipulating this challenge. Or perhaps they simply do not desire to because of cultural, religious or family ethics of "working hard" rather than relying on "working the system."

Motives for both the Asian and Latino college students are clearly beyond the parameters of the present study - interesting as it may be.

\section{IMPLICATIONS}

\section{1) The Millennial Generation May be More Ethical than their Boomer Parents}

They are not their "Daddy's Buick," - they reflect more the generation of their grandparents and indeed are often called the "new great generation." Having been raised in the homes of divorced parents and left alone as "latchkey" kids for countless hours they are likely saying "no" to flower children "me first" Clinton-esk ethics. Certainly they are no different than the children of the 1950's and maybe to quote Robert Kipling, "You're a better man than I am, Gunga Din" (1939) rings very true with these new well grounded twenty year olds.

\section{2) Men and Women Have Truly Grown Closer in Values in this new Post-Feminist Generation}

The battle may be over. Both men and women may be waving the white flag on the "battle between the sexes." The defensive postures of women's movements may be giving in to a generation that embraces collaboration above almost any other value Wikipedia, 2010; Tauber 2006). 


\section{3) Diversity Still Remains Amidst the Melting Pot}

America remains richly different. Cultures still influence even when moderated by a single generation of Millennia collaborators. This fact may be the heart of why America is great and will remain relevant for yet another generation. We have an African-American President and ask any individual from the Millennial generation who put him there and they will be happy to tell you - they did it and this is the way America should be.

\section{CONCLUSION}

Cheating in Business Schools, the Millennial Generation and Racial Diversity: Has the Paradigm Shifted? The answer is clearly yes indeed and we may be better off because of it.

\section{AUTHOR INFORMATION}

David L. Mathison is Professor of Management at Loyola Marymount University, Los Angeles. Prior to joining LMU he served on the faculty of Indiana University and Utah State University. His teaching interests include Business and Society, Corporate Leadership and Power within the Organization. He has some 60 published articles and was nominated for "Professor of the Year" by the LMU community in 2010.

\section{REFERENCES}

1. Baird, J. (2006). Current Trends in College Cheating, Psychology in the Schools, 17(4), 515-522.

2. Baker, R. (2000). Cultural and Gender Differences in Moral Judgment: A study of Mexican-Americans and Anglo-Americans, Hispanic Journal of Behavioral Sciences, 22(1), 78-93.

3. Beltramini, R. et al. (2004). Concerns of College Students Regarding Business Ethics, Journal of Business Ethics, 12(1), 195-200.

4. $\quad$ Beucke, D. (2006), "Biz Majors Get an F for Honesty,” Business Week, Feb 6, 14.

5. Davis, S. et al. (1995). Additional Data on Academic Dishonesty and a Proposal for Remediation, Teaching of Psychology, 22(2), 119-127.

6. Diekhoff, G. et al. (1999). College Cheating in Japan and United States, Research in Higher Education, 40(3), 343-353.

7. $\quad$ Diekhoff, G. et al. (1996). College Cheating: 10 Years Later, Research in Higher Education, 37(4), 487502.

8. $\quad$ Editor (2010). Generation Y, en.wikipedia.org

9. $\quad$ Editor (1999). Generation Y, Business Week, Feb 15, 23-25.

10. Editor (2010). Interesting Stats About Today's College Student, www.marketinginprogress.com

11. Editor (2010), "Memorable Quotes for Gunga Din - 1939," www.imdb.com

12. Goodwin, J. et al. (1999). Ethical Judgment Across Cultures, Journal of Business Ethics, 18(3), $267-281$.

13. Haines, V. et al. (1986). College Cheating: Immaturity, Lack of Commitment and the Neutralizing Attitude, Research in Higher Education, 21(4), 342-354.

14. Harp, J. et al. (1966). Academic Integrity and Social Structure: A study of Cheating Among College Students, Social Problems, 13(4), 365-373.

15. Karlins, M. et al. (1988). An Empirical Investigation of Actual Cheating in a Large Sample of Undergraduates, Research in Higher Education, 29(4), 359-364.

16. Kerkvliet, J. et al. (1999). Can We Control Cheating in the Classroom? Journal of Economic Education, 30(4), 331-343.

17. Klein, H. et al. (2007). Cheating During the College Years: How Do Business School Students Compare? Journal of Business Ethics, 72(2), 197-206.

18. Lanier, M. (2006). Academic Integrity and Distance, Journal of Criminal Justice Education, 17(2), 244261.

19. Livesky, M. et al. (2006). Views of Cheating Among College Students and Faculty, Psychology in the Schools, 31(1), 72-82.

20. Malinowski, C. (2004). Differences in Ethical Attitudes of Undergraduates of Asian and U.S. Ancestry, Advances in Competitiveness Research, 3(1), 26-31. 
21. Maramark, S. et al. (1993). Academic Dishonestly Among College Students, Issues in Education, 8(1), 123-144.

22. McCabe, D. (2005). Cheating among College and University Students: A North American Perspective, International Journal of Education, 16(1), 217-224.

23. McCuddy, M., et al (1996). Selected Individual Differences and Collegians Ethical Beliefs, Journal of Business Ethics, 15(3), 261-272.

24. Myaw, M. et al. (1994). A Comparative Analysis of Ethical Beliefs: A Four Country Study, Journal of Business Ethics, 13(7), 543-555.

25. Palmer, P. (1987), "Community, Conflict and Ways of Knowing," Change, 19(5), 20-25.

26. Premeaux, S. (2005). Undergraduate Student Perceptions Regarding Cheating: Tier 1 versus Tier 2 AACSB Accredited Business Schools, Journal of Business Ethics, 62, 407-418.

27. Shepherd, P. et al. (2002). An Inquiry into the Ethical Perceptions of Sub-Cultural Groups in the US: Hispanics versus Anglos, Journal of Consumer Marketing, 19(2), 130-148.

28. Smith, K. et al. (2004). An Examination of Cheating and Its Antecedents among Marketing and Management Majors, Journal of Business Ethics, 50, 63-80.

29. Smyth, L. et al. (2009). "Students' Perception of Business Ethics: Using Cheating as a Surrogate for Business Situations," Journal of Education for Business, 7(2), 212-215.

30. Stipek, D. (1998). Differences Between Americans and Chinese in the Circumstances Evoking Pride, Shame and Guilt, Journal of Cross-Cultural Psychology, 29(5), 616-629.

31. Stone, A. (2008). Generation Y-Not? Today's Teen Work Ethics are Hazy, San Diego Business Journal, March 17, 23-24.

32. Sweeney, R. (2005). Reinventing Library Buildings and Services for the Millennial Generation, Library Administration, 19(4), 165-175.

33. Trimble, J. et al. (2003). The Handbook of Ethical Research with Cross-Cultural Populations and Communities, Thousand Oaks, CA: Sage Publications.

34. Thompson, L. et al. (1995). But I Changed Three Words! Plagiarism in the ESL Classroom, The Clearing House, 69(1), 27-31.

35. Thompson, J. et al. (2004). The Relationship Between Tolerance for Ambiguity and Students' Propensity to Cheat on a College Exam, Journal of College Teaching and Learning, 2(1), 63-72.

36. Ward, D. et al. (1990). Gender and Dishonesty, Journal of Social Psychology, 131(30), 333-339.

37. Zastrow, C. (1970). Cheating Among College Graduate Students, The Journal of Educational Research, 64(4), 157-160. 


\section{NOTES}

